\title{
Natural history notes and conservation of a Saffron-cowled Blackbird Xanthopsar flavus population in the southern coastal plain of Rio Grande do Sul, Brazil
}

\author{
RAFAEL A. DIAS and GIOVANNI N. MAURÍCIO
}

\begin{abstract}
Summary
Saffron-cowled Blackbird Xanthopsar flavus is a globally threatened icterid of open areas of south-eastern South America. Several sources suggest that the species is declining throughout its range, mainly due to habitat destruction. Between December 1997 and December 1999 we studied a breeding population of X. flavus at the Banhado do Vinte-e-Cinco and Banhado da Mulata area, Rio Grande municipality, Rio Grande do Sul state, Brazil. This population, previously unreported for the state's coastal plain, numbers at least 60 individuals and seems confined to an area of $c .35 \mathrm{~km}^{2}$. The area is characterized by Cyperacaea-dominated peat marshes in comparatively higher terrain, covered with sandy, rolling fields. The species was recorded in all months (not necessarily of the same year) except March, and a marked irregularity in flock size was detected. During the non-breeding period, flock size averaged 12.7 individuals (S.D. $=11.7 ;$ range $=2-37 ; n=$ 11). During the 1997-1998 breeding season (December to January), mean flock size was 25.3 individuals (S.D. $=16.2$; range $=16-60 ; n=7$ ), while in the $1998-1999$ and 19992000 breeding seasons, 33 and 4 individuals were recorded respectively. No pronounced discrepancy was found in the size of the largest flocks recorded per season (from 20 to 37 individuals), suggesting that the population is sedentary and that it undertakes only local movements. A nesting colony occupying the same part of the marsh in two successive breeding seasons was composed of six breeding pairs in 1997-1998, with an estimated nesting success of $31.8-36.3 \%$ at fledgling time. The species is highly gregarious and sociable, foraging flocks frequently following individuals of Black-and-White Monjita Heteroxolmis dominicana and, to a lesser extent, Yellow-rumped Marshbird Pseudoleistes guirahuro and Brown-and-yellow Marshbird P. virescens. Although habitat loss has been indicated as the main factor for the species' decline, we suggest that habitat perturbation and modification may affect negatively recruitment rates in the species and, theoretically, its overall population size. Furthermore, the conservation of Rio Grande's peat marshes should be regarded a regional priority, in order to preserve threatened birds and a very unusual wetland type.
\end{abstract}

\section{Resumo}

O veste-amarela, Xanthopsar flavus, é um icterídeo globalmente ameaçado, ocorrendo nas áreas abertas do sudeste da América do Sul. Várias fontes sugerem que a espécie tem declinado numericamente, principalmente devido à destruição do seu hábitat. Entre dezembro de 1997 e dezembro de 1999 nós estudamos uma população reprodutiva de X. 
flavus na região do Banhado do Vinte-e-Cinco e Banhado da Mulata, município de Rio Grande, Rio Grande do Sul, Brasil. Esta população, previamente desconhecida na planície costeira do referido estado, foi estimada como tendo um número mínimo de 60 indivíduos, estando aparentemente confinada a uma área de c. $35 \mathrm{~km}^{2}$, caracterizada pela presença de banhados de turfa dominados por Cyperaceae, incrustados em terrenos comparativamente mais elevados, cobertos por campos arenosos ondulantes. A espécie foi registrada em todos os meses do ano (não necessariamente do mesmo ano), com exceção de março, e uma marcante irregularidade no tamanho dos bandos foi observada. Durante a estação não-reprodutiva, o tamanho médio dos bandos foi de 12.7 individuos (d.p. $=11.7 ;$ amplitude $=2-37 ; n=11$ ). A estação reprodutiva ocorreu entre Dezembro e Janeiro. Durante a estação reprodutiva de 1997-1998, o tamanho médio dos bandos foi de 25.3 indivíduos (d.p. = 16.2; amplitude $=16-60 ; n=7$ ), enquanto nas estaçães reprodutivas de 1998-1999 e 1999-2000 foram registrados 33 e 4 indivíduos, respectivamente. Os maiores bandos registrados por estação não apresentaram discrepância numérica pronunciada (entre 20 e 37 indivíduos), sugerindo que a população é sedentária e efetua apenas movimentos locais. Uma colônia reprodutiva que ocupou o mesmo local do banhado foi registrada em duas estações reprodutivas consecutivas, sendo composta por seis pares em 1997-1998 e tendo um sucesso reprodutivo estimado em 31.8-36.3\%. A espécie é altamente gregária e sociável, e bandos forrageadores freqüentemente acompanham individuos da noivinha-de-rabo-preto Heteroxolmis dominicana e, em menor escala, do chopim-do-brejo Pseudoleistes guirahuro e do dragão P. virescens. Apesar da perda de habitat ter sido indicada como o principal fator de declínio da espécie, nós sugerimos que a perturbação e a modificação deste podem afetar negativamente as taxas de recrutamento da espécie e, teoricamente, o tamanho populacional como um todo. Ademais, a conservação dos banhados de turfa de Rio Grande deve ser considerada uma prioridade regional, visando preservar aves ameaçadas e um tipo peculiar de área úmida.

\section{Introduction}

Saffron-cowled Blackbird Xanthopsar flavus ranks among the most threatened birds of Neotropical temperate grasslands, being currently classified as Vulnerable (Birdlife International 2000) and considered a high conservation and research priority in the continent (Parker et al. 1996). Throughout its geographical distribution, which encompasses southern Brazil, eastern Paraguay, Uruguay, and north-eastern Argentina, this colonial icterid has experienced a considerable decline and range contraction, which have been attributed to the many different human uses of the open country in which it lives (Collar et al. 1992). Further information on its distribution, ecology and remaining breeding areas is required to outline an international conservation strategy for the species (Collar et al. 1992). Nevertheless, the few published studies focusing on the species (e.g. Klimaitis 1984, 1986, Fraga 1990, Fraga et al. 1998) cover only a limited part of its range. In Brazil, where the species is thought to be more numerous (Ridgely and Tudor 1989), available information on its natural history and conservation status is scanty, and derived from studies or limited observations carried out entirely in the extreme north-eastern corner of Rio Grande do Sul state (Collar et al. 1992, Belton 1994, Fontana 1994).

In this paper, we report on the first observations of the ecology and breeding biology of X. flavus in the southern portion of Rio Grande do Sul's coastal plain, Brazil, and also present suggestions for its conservation in this region. 


\section{Methods}

We studied $X$. flavus primarily within and in the immediate vicinity of Banhado do Vinte-e-Cinco (Figures 1 and 2), a marsh near the village of Domingos Petrollini, municipality of Rio Grande. Between December 1997 and December 1999, we visited monthly (except in September 1999) an area of c. $0.5 \times 1 \mathrm{~km}$ along the edge of the marsh at the agricultural station of Fundação Estadual de Pesquisa Agropecuária (FEPAGRO) $\left(31^{\circ} 59^{\prime} \mathrm{S}, 52^{\circ} 17^{\prime} \mathrm{W}\right.$, all co-ordinates from maps of the Cartographic Service of the Brazilian Army with a 1:50,000 scale). Fieldwork was carried out on one day per month, accumulating 115 hours of observations (additional data were gathered on other occasions). Observations were conducted mainly in the afternoon, except from May 1999 onwards, when we worked primarily during the morning in order to monitor possible differences in daytime activities. Sporadically, we looked for X. flavus in other sectors of the marsh and once, on 17 February 1998, briefly made observations in the adjacent Banhado da Mulata $\left(31^{\circ} 57^{\prime} \mathrm{S}, 52^{\circ} 16^{\prime} \mathrm{W}\right)$, a marsh whose long lateral branches practically connect it with Banhado do Vinte-e-Cinco. Additionally, during the 1997-1998 breeding season, we made more intensive observations (total of seven days spent afield) at a nesting colony in the FEPAGRO station. Whenever possible, we followed X. flavus flocks for about one hour, except during the breeding season, when we spent two or more hours observing nesting activities.

\section{Results}

\section{Distribution and old records}

In the southern coastal plain of Rio Grande do Sul, X. flavus seems to be confined to a limited area of comparatively higher terrain (10-20 $\mathrm{m}$ a.s.l.) located between the lowlands of the Laguna dos Patos estuary and the Canal de São Gonçalo, which lie almost at sea level (Figure 2). In this area, we found the species only at Banhado do Vinte-e-Cinco and Banhado da Mulata (including neighbouring grasslands). Extensive ornithological surveys conducted by us at several other wetland sites in the coastal plain of the state failed to reveal additional localities for the species (Table 1, Figure 1).

All previous records of $X$. flavus from this region, except for one, can be regarded as doubtful. The records for Pelotas mentioned by Ihering (1899) and Hellmayr (1937) cannot be certainly ascribed to the coastal plain, since areas with suitable habitat in the hilly region of the adjacent Serra do Sudeste were formerly a part of this municipality. The old specimens mentioned by Collar et al. (1992) for the municipality of Rio Grande have on their labels the sole indication of "Rio Grande" (T. M. Brooks, M. Adams and P. Sweet, in litt. to RAD), an imprecise locality designation considering that this toponym was formerly used without the postfix "do Sul" to designate the whole state of Rio Grande do Sul (Ihering 1899). The only reliable record from the state's coastal plain is thus that of T. A. Parker III (in Collar et al. 1992) for an unspecified locality between Pelotas and Rio Grande. Since Banhado do Vinte-e-Cinco and Banhado da Mulata are located between these two cities and crossed by highway BR-392, we believe this record was obtained at one of these localities. 


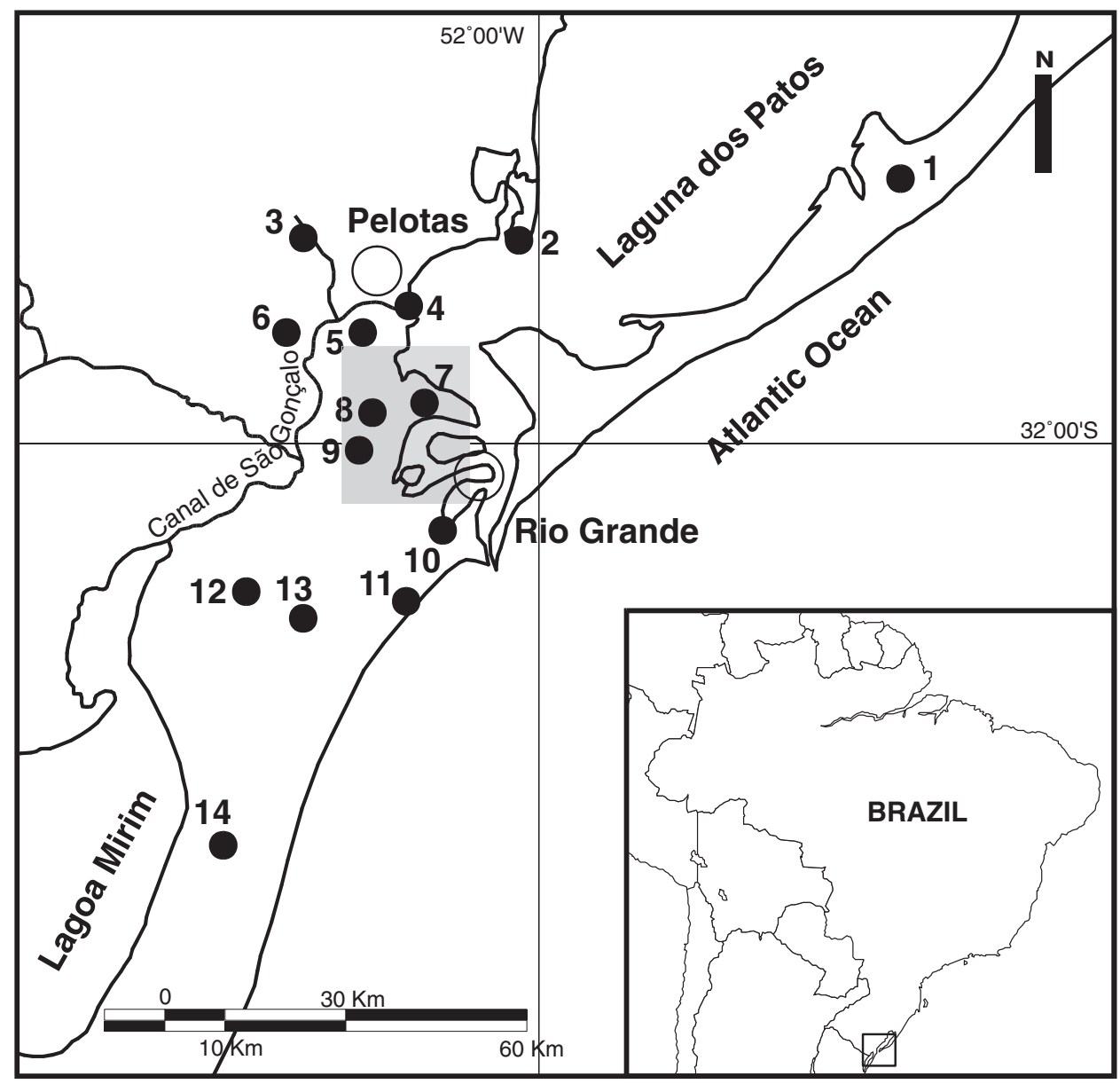

Figure 1. Map showing wetland sites surveyed in the southern coastal plain of Rio Grande do Sul, Brazil: 1, Banhado do Capão da Areia; 2, Ilha da Feitoria; 3, Arroio Santa Bárbara; 4, Banhado do Pontal da Barra; 5, Canal de São Gonçalo - Capão Seco; 6, Canal de São Gonçalo - EMBRAPA; 7, Banhado do Silveira/Ilha da Torotama; 8, Banhado da Mulata; 9, Banhado do Vinte-e-Cinco; 10, Saco da Mangueira; 11, SW Praia do Cassino; 12, Granja Quatro Irmãos; 13, Banhado do Maçarico; 14, Banhado do Taim. The shading indicates the area depicted in Figure 2.

\section{Habitat}

In the study area, X. flavus occupied a landscape mainly characterized by sandy, rolling fields of Pleistocene-aged sediments eroded by fluvial paleovalleys. The latter were subjected to progressive natural sedimentation and, after the highest Holocene marine transgression about 4,00o years ago (Cordeiro and Lorscheitter 1994), originated peat marshes of variable sizes (H. E. Asmus, verbally). Banhado do Vinte-e-Cinco, the largest of these peat marshes, is a narrow, 400-1,000 m wide and $12 \mathrm{~km}$ long marsh of $c$. $800 \mathrm{ha}$, with some lateral branches on its northern edge. The tall saw grasses Cladium jamaicensis and Scirpus giganteus 
Table 1. Wetland sites surveyed by the authors in the southern coastal plain of Rio Grande do Sul from where Saffron-cowled Blackbird Xanthopsar flavus, has not been recorded, with total sampling effort and seasonal coverage

\begin{tabular}{|c|c|c|c|c|}
\hline Site & Coordinates & Effort & Seasons & $\begin{array}{l}\text { Additional } \\
\text { references }\end{array}$ \\
\hline Banhado do Capão da Areia & $31^{\circ} 33^{\prime} \mathrm{S}, 51^{\circ} 15^{\prime} \mathrm{W}$ & a & W-Sp & - \\
\hline Ilha da Feitoria & $31^{\circ} 38^{\prime} \mathrm{S}, 52^{\circ} \mathrm{O} 2^{\prime} \mathrm{W}$ & $\mathrm{b}$ & S-W-Sp & - \\
\hline Arroio Santa Bárbara & $31^{\circ} 40^{\prime} \mathrm{S}, 52^{\circ} 26^{\prime} \mathrm{W}$ & $\mathrm{b}$ & S-A-W-Sp & - \\
\hline Banhado do Pontal da Barra & $31^{\circ} 47^{\prime} \mathrm{S}, 52^{\circ} 14^{\prime} \mathrm{W}$ & d & S-A-W-Sp & - \\
\hline Canal de São Gonçalo - Capão Seco & $31^{\circ} 48^{\prime} \mathrm{S}, 52^{\circ} 20^{\prime} \mathrm{W}$ & $\mathrm{d}$ & S-A-W-Sp & - \\
\hline Canal de São Gonçalo - EMBRAPA & $31^{\circ} 48^{\prime} \mathrm{S}, 52^{\circ} 26^{\prime} \mathrm{W}$ & a & S-A-W-Sp & - \\
\hline $\begin{array}{l}\text { Banhado do Silveira/Ilha da } \\
\text { Torotama }\end{array}$ & $31^{\circ} 55^{\prime} \mathrm{S}, 52^{\circ} 12^{\prime} \mathrm{W}$ & $\mathrm{b}$ & S-A-W-Sp & - \\
\hline Saco da Mangueira & $32^{\circ} \mathrm{O} 2^{\prime} \mathrm{S}, 52^{\circ} \mathrm{O} 6^{\prime} \mathrm{W}$ & c & S-A-W-Sp & $\begin{array}{l}\text { Dias and Maurício } \\
1998\end{array}$ \\
\hline SW Praia do Cassino & $32^{\circ} 11^{\prime} \mathrm{S}, 52^{\circ} 10^{\prime} \mathrm{W}$ & $\mathrm{b}$ & S-A-W-Sp & - \\
\hline Granja Quatro Irmãos & $32^{\circ} 12^{\prime} \mathrm{S}, 52^{\circ} 35^{\prime} \mathrm{W}$ & c & S-A-W-Sp & - \\
\hline Banhado do Maçarico & $32^{\circ} 16^{\prime} \mathrm{S}, 52^{\circ} 12^{\prime} \mathrm{W}$ & a & S-A-W-Sp & - \\
\hline Banhado do Taim & $32^{\circ} 32^{\prime} \mathrm{S}, 52^{\circ} 32^{\prime} \mathrm{W}$ & $\mathrm{b}$ & S-A-W-Sp & Mähler et al. 1996 \\
\hline
\end{tabular}

Codes for sampling effort: a, less than 100 hours afield; b, 100-200 hours; c, 200-300 hours; d, more than 300 hours. Seasons: S, summer; A, autumn; W, winter; Sp, spring.

(Cyperaceae) cover most of the inner portions of the marsh, with Eryngium pandanifolium (Apiaceae), herbaceous vegetation and grasses growing in several sectors of its edge. Corticeira trees, Erythrina cristagalli (Fabaceae), and small bushes occur in some places, while restinga forests line some of the margins, frequently invading the marsh. The sandy rolling fields adjacent to the marsh are presently used for agriculture, cattle grazing, and Eucalyptus sp. afforestation.

Climate in Rio Grande municipality is classified as humid to subhumid (IBGE 1986). Mean rainfall and temperature throughout the year are as follows: summer, $246.7 \mathrm{~mm}, 22.8^{\circ} \mathrm{C}$; autumn, $298.6 \mathrm{~mm}$, $19.1{ }^{\circ} \mathrm{C}$; winter, $328.4 \mathrm{~mm}, 13.3$ ${ }^{\circ} \mathrm{C}$; spring, $288.1 \mathrm{~mm}, 17.1{ }^{\circ} \mathrm{C}$ (CLIMANÁLISE 1986).

\section{Seasonality and flock size}

With the exception of March, X flavus was recorded in all months of the year. January, May, June, November and December were the only months in which we recorded the species in both study years. We excluded from the analysis two males recorded in November 1998 and a flock of 25 individuals observed on 02 January 1999, both detected outside the sampling period.

There was a marked difference in the mean number of individuals detected per flock between the two years of observations. In the non-breeding period of 1998 (February to November), the average number of individuals detected was 5.3 (S.D. $=4.9$; range $=2-15 ; n=6$ ), while in the same season of 1999 (January to November) it was 21.6 (S.D. $=11.5$, range $=5-37 ; n=5)$. We never recorded more than one flock during the counting period in the non-breeding season. A single individual observed in August 1999 was excluded from the analysis, since it was not considered a flock. The larger mean flock size verified in 1999 was probably related to the time of the day in which the data were collected. Most of the large 


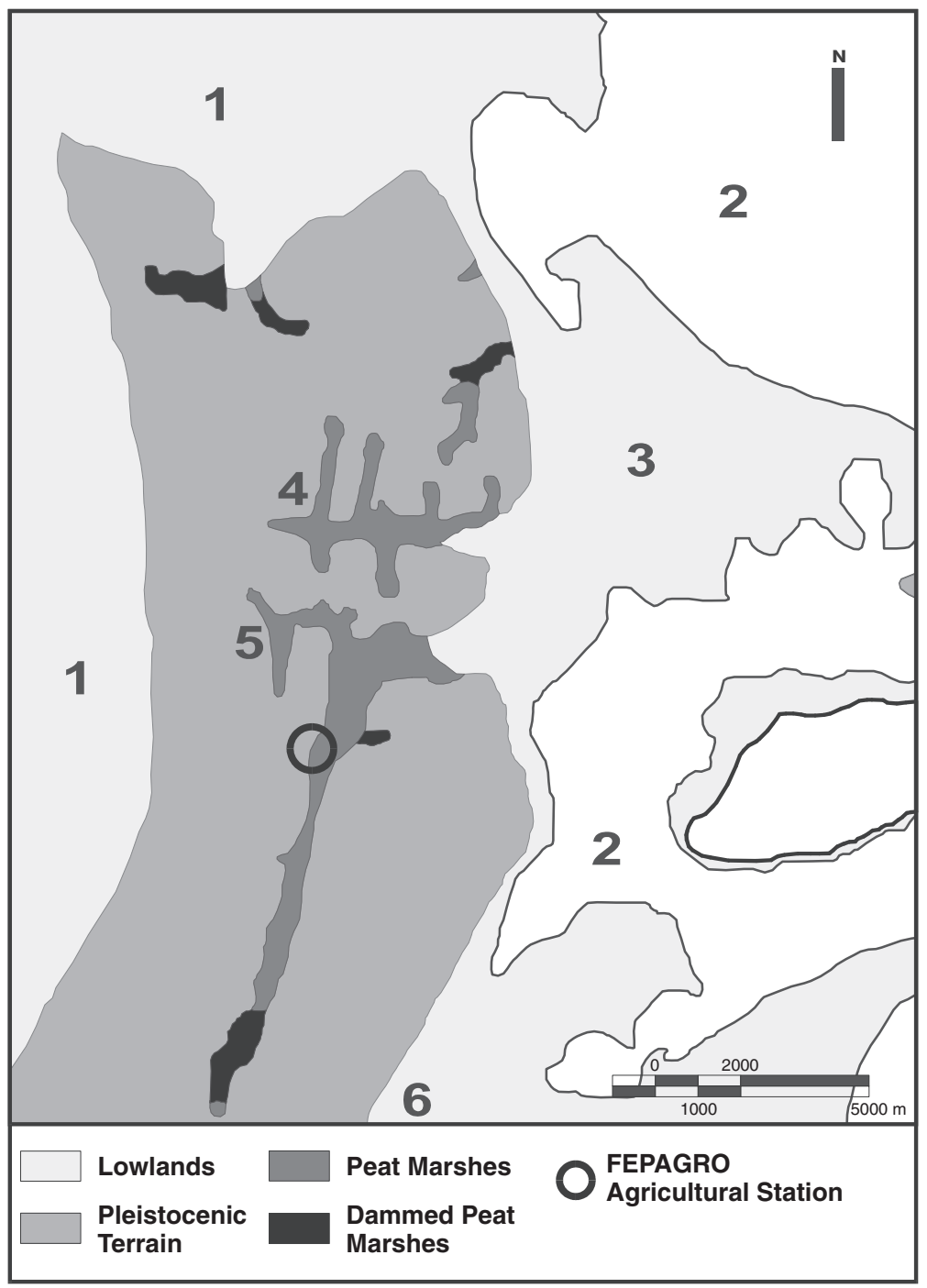

Figure 2. Map showing the Banhado-do-Vinte-e-Cinco and Banhado-da-Mulata region, Rio Grande do Sul, Brazil. 1, Canal de São Gonçalo floodplain marshes; 2, Lagoa dos Patos estuary; 3, Ilha da Torotama; 4, Banhado da Mulata; 5, Banhado do Vinte-e-Cinco; 6, Northern sector of Banhado do Maçarico.

flocks were detected from May onwards, when we worked in the morning (such large flocks were not observed after 12hoo). Considering data from both years, flock size in the non-breeding period averaged 12.7 individuals $($ S.D. $=11.7$; range $=2-37 ; n=11)($ Table 2$)$.

In the breeding period, which we found to extend from December through January (see Breeding), mean flock size was more difficult to determine because groups frequently changed composition as they flew between the nesting colony and feeding sites. To estimate flock size in this period, we considered only the 
Table 2. Total number of individuals of Saffron-cowled Blackbird Xanthopsar flavus, presence of associating species, and associations recorded per month at the Banhado do Vinte-e-Cinco during 1998-1999

\begin{tabular}{lllllll}
\hline & January & & February & & March & \\
& 1998 & 1999 & 1998 & 1999 & 1998 & 1999 \\
\hline No. of individuals & 16 & $21^{*}$ & 5 & 0 & 0 & 0 \\
Assoc. spp. present & HD,PG & PG,PV & PG & - & PG & - \\
Association recorded & HD,PG & PG,PV & - & - & - & - \\
\hline & April & & May & & June & \\
& 1998 & 1999 & 1998 & 1999 & 1998 & 1999 \\
\hline No. of individuals & 15 & o & 2 & $37^{*}$ & 4 & $5^{*}$ \\
Assoc. spp. present & HD & HD & - & HD,PG,PV & - & HD,PG,PV \\
Association recorded & - & - & - & HD & - & HD \\
\hline & July & & August & & September & \\
& 1998 & 1999 & 1998 & 1999 & 1998 & 1999 \\
\hline No. of individuals & o & $25^{*}$ & o & 1 & 4 & - \\
Assoc. spp. present & - & HD,PG,PV & - & - & HD,PG,PV & - \\
Association recorded & - & HD,PG & - & - & HD,PG & - \\
\hline & October & & November & & December & \\
\hline No. of individuals & $2^{*}$ & o & o & $20^{*}$ & 33 & 4 \\
Assoc. spp. present & HD,PG & - & - & HD & HD,PV & HD \\
Association recorded & HD & - & - & HD & HD,PV & HD \\
\hline
\end{tabular}

Breeding season records are in italic. ${ }^{*}$ Feeding individuals recorded during the non-breeding season. Species acronyms: HD, Heteroxolmis dominicana; PG, Pseudoleistes guirahuro; PV, Pseudoleistes virescens.

largest flock recorded per day, which roughly corresponded to the number of individuals in the colony. Thus, in the 1997/1998 breeding season, the mean flock size was 25.3 (S.D. $=16.2$; range $=16-60 ; n=7$ ) (Table 3 ). The record of 60 individuals, numerically much larger than that of 16 individuals observed in the colony during the first half of January 1998, resulted from the arrival of a possible post-breeding flock of $c .40$ individuals, which mingled with the local group on one occasion. In the breeding seasons of 1998/1999 and 1999/2000, 33 and 4 individuals respectively were recorded at the colony (see Breeding).

Table 3. Number of individuals of Saffron-cowled Blackbird Xanthopsar flavus, presence of associating species, and associations recorded at the Banhado do Vinte-e-Cinco during the 1997-1998 breeding season

\begin{tabular}{llllllll}
\hline & 31 Dec & 08 Jan & 12 Jan & 21 Jan & 24 Jan & 26 Jan & 29 Jan \\
\hline No. of individuals & 16 & 16 & 16 & 60 & 16 & 30 & 23 \\
Assoc. spp. present & HD & PG & HD,PG & PG & HD & - & - \\
Association recorded & HD & PG & HD,PG & PG & HD & - & - \\
\hline
\end{tabular}

Species acronyms: HD, Heteroxolmis dominicana; PG, Pseudoleistes guirahuro. 


\section{Foraging behaviour and mixed flocks}

The most common foraging sites used by X. flavus throughout the year were abandoned agricultural fields, which were generally covered with short grasses, well-spaced herbs or sand-dwelling Cyperaceae. In the breeding period, birds also commonly foraged in a cornfield adjacent to the marsh, taking caterpillars and grasshoppers from corn leaves. Foraging in bare ground was recorded a few times. In the nesting colony, some individuals seemed to forage amongst the marsh vegetation. At the Banhado da Mulata area, we saw a pair and a group of four birds foraging on a natural field. The latter group also foraged among grasses in shallow water of the adjacent marsh. With the exception of breeding individuals occasionally foraging amidst leaves of corn or marsh vegetation, birds usually foraged by walking on the ground, probing the soil or vegetation.

Throughout the non-breeding season (February to November 1998; January to November 1999), foraging flocks averaged 16.2 individuals (S.D. $=13$; range $=2-$ $37 ; n=7$ ) (Table 2). During the breeding season, birds were often foraging, but numbers were difficult to determine for the same reason mentioned above.

Foraging flocks of X. flavus frequently associated with other bird species. An association with Black-and-white Monjita Heteroxolmis dominicana was recorded throughout the year at Banhado do Vinte-e-Cinco, where this tyrannid is a fairly common year-round resident. At this site, we also recorded X. flavus in mixed species flocks with Yellow-rumped Pseudoleistes guirahuro, and Brown-andyellow Marshbird P. virescens.

Foraging X. flavus flocks were associated with $H$. dominicana pairs or families on all six occasions in which these species were observed simultaneously at the FEPAGRO station during the non-breeding season (Table 2). The two X. flavus groups recorded at Banhado da Mulata were also associated with $H$. dominicana, but of six simultaneous non-breeding season records of X. flavus and P. guirahuro at Banhado do Vinte-e-Cinco, they were associated on only three. H. dominicana was absent on one occasion, on another it abandoned the foraging blackbird flock for unknown reasons and on another it appeared to be resting on marsh vegetation. On the five occasions during the non-breeding season in which H. dominicana and P. guirahuro were recorded foraging simultaneously in the area, $X$. flavus favoured the former in all cases, except once when it followed both species without a clear preference, apparently seeking the latter only when the former was resting. In most cases, the blackbirds followed every displacement of the monjitas, including long distance flights (e.g. $200 \mathrm{~m}$ or more).

During the breeding season of 1997/1998, we found X. flavus associated with $H$. dominicana and P. guirahuro three times, favouring the former on the few occasions on which it was present (Table 3). On 26 January 1998 a blackbird flock apparently associated with a Fork-tailed Tyrant Tyrannus savana in a cornfield edge. In late January 1998, we found X. flavus foraging primarily alone, as $H$. dominicana and $P$. guirahuro were absent during our observations. In the next two breeding seasons we again recorded X. flavus in mixed-flocks, mainly with $H$. dominicana. Association with $P$. virescens occurred only once, when this marshbird and $X$. flavus bred together in a mixed colony at the FEPAGRO station in December 1998. However, the blackbirds foraged with the marshbirds only while 
H. dominicana (a family in this case) was resting in the marsh; after the latter resumed foraging in the adjacent fields, the blackbirds sought its company and followed it closely. Monospecific foraging flocks of X. flavus were observed on few occasions, mainly during the 1997/1998 breeding period, when the blackbirds foraged inside a cornfield where other birds did not enter. At this time, one or more blackbirds acted as sentinels.

\section{Breeding}

At the FEPAGRO station, a nesting colony occupied the same portion of the marsh in two successive breeding seasons. The colony occupied less than 0.5 ha, where the vegetation was composed primarily of a dense growth of $C$. jamaicensis and S. giganteus, with some dispersed small bushes (sarandis and corticeiras) and E. pandanifolium sedges on the border. Water depth in this area ranged from 30 to $50 \mathrm{~cm}$.

The first colony was studied between 31 December 1997 and 29 January 1998. It was composed of six breeding pairs, whose presumed nest sites were 10-20 m distant from each other. We were able to locate only one nest, which contained three very young nestlings on 31 December. This nest, found empty on 8 January, was located c. $15 \mathrm{~m}$ from the marsh edge and about $50 \mathrm{~cm}$ above the water surface, being fixed in S. giganteus leaves and partially overshadowed by an E. pandanifolium. The remaining nests were located more in the interior of the marsh and had their approximate location inferred through the observation of the adult's behaviour. Three were situated in the mixed stand of $C$. jamaicensis and S. giganteus. Two other pairs fed their fledglings (two per pair) in the sarandi bushes, where their nests were presumably situated.

The arrival of a possible post-breeding flock with $c$. 40 individuals in the colony caused a numerical increase in both adults and young on 21 January or shortly before. On this occasion, in a flock of about $30 \mathrm{X}$. flavus resting in the colony area, 12 were juveniles, some of which were fed with caterpillars and grasshoppers taken in the adjacent cornfield. On 26 and 29 January, about 30 and 23 individuals respectively were detected in the colony. At this time some juveniles were still being fed with caterpillars by their parents. In early February no $X$. flavus was seen in the colony area.

The following breeding period started earlier, with a nesting colony found in a relatively advanced stage on 24 December 1998, and up to 33 individuals detected in the area. Two or three pairs brought food to unseen nestlings in the interior of the cyperaceous stand, while three or four others fed juveniles out of their nests. The remaining birds were apparently non-breeding individuals, but they moved back and forth from the colony area several times in a morning, generally following a family of $H$. dominicana or a group of $P$. virescens. On 2 January 1999, about 25 X. flavus followed a $H$. dominicana pair into the adjacent fields, where adults fed some juveniles. The activities in the nesting colony had practically finished at this time. Thus a group of $21 X$. flavus recorded on 16 January was regarded as a post-breeding flock, even though it occurred at a time of year when the species was found nesting in the previous breeding season.

In the 1999/2000 breeding season, no nesting colony was established in the 
traditional area at the FEPAGRO station. However, the record of a female carrying food on 4 December 1999 could suggest that a nesting colony was established in the nearby eastern sector of Banhado do Vinte-e-Cinco or in some of its branches. This possible change in colony location could be related to the dry condition of the cyperaceous cover, which was completely burnt in late December 1999.

Nesting success could not be assessed accurately from the available data, but an estimate was tentatively obtained for the first colony studied. Most of the 12 juveniles recorded among $c$. 18 adults on 21 January 1998 certainly were not born in the FEPAGRO station, but presumably came from another colony in Banhado do Vinte-e-Cinco or Banhado da Mulata as part of a post-breeding flock. The juveniles that we assume to have been born in the FEPAGRO colony included only the four fledglings and the three or four recently fledged young seen on 26 January. Therefore, from the six nests in the colony, at least four $(60 \%)$ were successful in producing some fledglings, apparently two per adult pair. As no counts of eggs were made, the total nesting success was estimated by using the average clutch size of 3.67 eggs found by Fraga et al. (1998) for 12 non-parasitized $X$. flavus nests in Argentina. Based on this information, the total clutch laid in the FEPAGRO colony would have been $c .22$ eggs. Thus, considering that the total number of fledged young was seven or eight, nesting success would have been $31.8-36.3 \%$ at fledgling time. Shiny Cowbird Molothrus bonariensis is commonly observed at the Banhado do Vinte-e-Cinco area, but evidence of broodparasitism was not recorded in the FEPAGRO colony.

\section{Discussion}

\section{Natural History}

The two peat marshes where we found X. flavus together form a striking network of swampy valleys bordered on both sides by rolling fields, closely resembling the landscape of open rolling pastureland and small boggy swales described by Belton (1985) for the species in the highlands of southeastern and northeastern Rio Grande do Sul (GNM, pers. obs.). In Argentina, this same combination of habitats was described for the species in Corrientes, although further south, in Entre Rios, it inhabits a somewhat drier land (Fraga et al. 1998). Our data suggest that in Rio Grande do Sul's southern coastal plain, X. flavus favours relatively restricted areas with narrow peat marshes in a Pleistocene terrain, avoiding extensive open marshes.

A remarkable irregularity in the flock size of $X$. flavus was found throughout the study period, but small numbers (2-4 individuals) were the rule between August and October. Although the available data showed a marked monthly fluctuation in numbers at the study site, the largest flocks recorded per season irrespective of the breeding stage - did not show pronounced numerical discrepancy (i.e. from 20 to 37 individuals), suggesting that the local population is sedentary and that it undertakes only minor movements, presumably within Banhado do Vinte-e-Cinco and also between this area and Banhado da Mulata. For many years we have worked in several field and marshy areas a few kilometres to the north, south and east of the study site and have never noticed the species' 
presence in these localities. The pattern of irregular eruptions - i.e. distance movements of populations without defined direction and number of individuals involved - suggested by Fraga (1990) and Collar et al. (1992) for X. flavus, is thus not consistent with out data, except perhaps, if regarded on a very local scale. Instead, our data suggest that the irregularity or seasonal absence of X. flavus reported by some authors in several known sites of the species (e.g. Barrows 1883, Gibson 1918, Klimaitis 1984, 1986, Collar et al. 1992) might in some instances be the result of local movements, which in turn may be related to periodical changes in nesting colony location (see Breeding).

The association of $X$. flavus with $H$. dominicana in heterospecific flocks was previously reported by some authors from Brazil (e.g. Belton 1985, Fontana 1994, Sick 1997) and Argentina (Fraga et al. 1998), while its association with P. guirahuro and P. virescens is known in Brazil only for the first species (Belton 1985, Fontana 1994, Sick 1997) and in Argentina for both (Gibson 1918, Fraga et al. 1998). When in mixed flocks, $X$. flavus probably benefits from the sentinel behaviour of its flock partners, increasing its feeding time (Fontana 1994). The preference of X. flavus for $\mathrm{H}$. dominicana rather than Pseudoleistes spp. as an associating species during foraging may be related to possible interspecific competition for food with the marshbirds, which forage on the ground in a manner similar to the blackbirds. As for the Monjita, there would be less or no such competition, since the tyrannid forages in a different manner (Fontana 1994). As in other studies (e.g. Fontana 1994, Fraga et al. 1998) sentinel behaviour by X. flavus was rarely recorded during our observations.

Breeding of X. flavus in Rio Grande do Sul has been reported only from the north-eastern highlands (Planalto), from where 9 or 10 nesting colonies are known (Belton 1985, Collar et al. 1992, Fontana 1994). Throughout the species range, nesting has been recorded both in dry (e.g. Gibson 1885, Pereyra 1938, Klimaitis 1984, 1986, Fraga et al. 1998) and marshy areas (e.g. Barrows 1883, Belton 1985, Ridgely and Tudor 1989, Fontana 1994, Fraga et al. 1998). In Brazil, in accordance with our data, breeding of $X$. flavus has been reported only in marshes (Belton 1985, Fontana 1994).

The total nesting success we estimated for the FEPAGRO colony (31.8-36.3\%) was considerably larger than the $8.4 \%$ estimated by Fraga et al. (1998) for a colony of 24 nests studied in Entre Rios, Argentina. However, important causes for nest failure in the Entre Rios colony - disturbance caused by cattle and brood parasitism - were not recorded in our study (see below).

\section{Conservation}

The implementation of effective conservation strategies concerning X. flavus is obstructed by the scarcity of thorough ecological and population studies. In Argentina, its conservation status has been recently evaluated on the basis of extensive bibliographical, museum and field surveys, which revealed that the population there has been reduced to 500-1000 individuals, apparently confined to two small and disjunct areas (Fraga et al. 1998). Although there are no estimates of the species' population size in Brazil, numbers in Rio Grande do Sul are believed to have declined in recent decades (Belton 1994). Our estimate of the population in the peat marshes of the southern coastal plain corresponds to the 
maximum number of 60 individuals observed in January 1998. The lack of adequate historical information on the former occurrence of the species in this area however, precludes any evaluation of numerical tendencies over the time. If the population known to have occurred in the adjacent municipality of Pelotas (Ihering 1899) occupied lowland areas, it is now certainly extirpated (G. N. Maurício and R. A. Dias, unpublished).

The overall decline of $X$. flavus has been related to habitat destruction and alteration (Collar et al. 1992). In a recent study, however, Fraga et al. (1998) suggested that some sources of habitat disturbance usually regarded as deleterious to the species, such as the expansion of cattle raising and agriculture, may not be major sources of decline. Nevertheless, if only agricultural areas and pastureland are available for nesting, the impact of cattle and agriculture may be significant. The strong contrast between the very low nesting success reported by Fraga et al. (1998) for a X. flavus colony in agropastoral fields and that estimated by us for a colony located in an undisturbed natural marsh suggests that in man-managed, disturbed places recruitment may be significantly lower than in pristine habitats. Besides cattle disturbance, a higher incidence of predation and cowbird parasitism may occur in nesting colonies located in man-modified environments when compared with undisturbed ones (cf. Fraga et al. 1998). Lower recruitment rates may severely affect the stability of the species' population over time. Although the potential impact of habitat alteration could theoretically lead to a continued global population decrease, habitat loss has more recently been considered the major threat to the species (Collar et al. 1997, Fraga et al. 1998).

The drainage of marshes and the replacement of open fields by pine plantations are the main factors responsible for the presumed population decrease of X. flavus in north-eastern Rio Grande do Sul (Fontana 1994, Bencke and Kendel 1999). These same factors are identified as the main reasons for the species' decline or disappearance in parts of Argentina, where cowbird parasitism and capture for the bird trade represent additional threats (Fraga et al. 1998).

In the region of our study, despite the past replacement of parts of open fields by eucalyptus stands (now stabilized), the major threat to X. flavus seems to be the damming of marshy valleys. Some peat marshes in this region, including the southern sector of Banhado do Vinte-e-Cinco, were dammed for irrigation, creating deep, open water lakes with steep banks completely devoid of marsh vegetation (see Figure 2). Banhado da Mulata, which is probably as important as Banhado do Vinte-e-Cinco for the local population of X. flavus, fortunately remains largely undisturbed. The species seems well adapted to live in agropastoral land (Fraga et al. 1998; pers. obs.) but at least locally it depends to a great extent on certain types of pristine marsh for breeding and resting (Belton 1985; this study). This makes the species especially vulnerable to agricultural and extraction projects involving marshes within its range (see below).

Although the species is protected under Brazilian law (Bernardes et al. 1990), protection areas from where it is known in Rio Grande do Sul include only the Aparados da Serra National Park (Parker and Goerck 1997) and, possibly, the adjacent Serra Geral National Park, both located in the states' north-eastern corner. No park or reserve is known to protect X. flavus in the coastal plain or even in the entire southern half of Rio Grande do Sul. Although the high mobility of the species in the non-breeding season poses difficulties for designing reserves 
(Frage et al. 1998), our results suggest that the $35 \mathrm{~km}^{2}$ of the Banhado do Vinte-eCinco-Banhado da Mulata complex encompasses the whole range of the local X. flavus population. The species' nearest known population is found c. $60 \mathrm{~km}$ to the west of our study site, in the municipality of Pedro Osório (I. Accordi, verbally to GNM), in the Serra do Sudeste, where Belton (1985) mapped a relatively large area for the species. Since this latter region is less disturbed compared with the coastal lowlands, which experience rapid and unplanned development, the conservation of the Banhado do Vinte-e-Cinco-Banhado da Mulata complex may represent a regional priority for the species. Moreover, at least two other threatened or near-threatened bird species occur in Banhado do Vinte-e-Cinco, Black-and-White Monjita and Straight-billed Reedhaunter Limnoctites rectirostris (RAD and GNM, unpubl. data). Recently, an application for permission to extract peat in Banhado do Vinte-e-Cinco was presented to the state environmental agency (FEPAM). Fortunately, the licence was not given, but this is a posture subject to change due to political and economical issues. Therefore, we suggest that available resources for wetland conservation in Rio Grande do Sul's coastal plain be applied to the protection of the Banhado do Vinte-e-Cinco-Banhado da Mulata complex, in order to protect threatened species of birds and a very unusual wetland type. Furthermore, we strongly recommend the continuation of studies on the natural history of X. flavus, especially on its demography and ecological requirements, as a possible unique way to understand and conserve this endangered species.

\section{Acknowledgements}

We are deeply indebted to Glayson A. Bencke, Gérman López, the editor and an anonymous reviewer for their valuable contributions to the manuscript. Mark Adams, Thomas Brooks and Paul Sweet kindly examined specimens at the American Museum of Natural History and the British Museum. We are also thankful to Eugenio Coconier, Luiz P. Gonzaga, Troy Gordon, Alvaro Jaramillo and José Fernando Pacheco for providing literature.

\section{References}

Barrows, W. B. (1883) Birds of the lower Uruguay. Bull. Nuttal. Orn. Club 8: 82-143.

Belton, W. (1985) Birds of Rio Grande do Sul, Brazil, 2. Formicariidae through Corvidae. Bull. Amer. Mus. Nat. Hist. 180: 3-241.

Belton, W. (1994) Aves do Rio Grande do Sul: distribuição e biologia. São Leopoldo: Unisinos.

Bencke, G. A. and Kindel, A. (1999) Bird counts along an altitudinal gradient of Atlantic forest in northeastern Rio Grande do Sul, Brazil. Ararajuba 7: 91-107.

Bernardes, A. T., Machado, A. B. M. and Rylands, A. B. (1990) Fauna brasileira ameaçada de extinção. Belo Horizonte: Fundação Biodiversitas.

Birdlife International (2000) Threatened birds of the world. Barcelona and Cambridge: Lynx Edicions and Birdlife International.

CLIMANÁLISE (1986) Boletim de monitoramento e análise climática. Aspectos da climatologia dinâmica no Brasil. Cachoeira Paulista: INPE/CPTEC.

Collar, N. J., Gonzaga, L. P., Krabbe, L. P., Madroño Nieto, N., Naranjo, L. G., Parker III, T. A. and Wege, D. C. (1992) Threatened birds of the Americas: the ICBP/IUCN Red Data Book. Cambridge, U.K.: International Council for Bird Preservation. 
Cordeiro, S. H. and Lorscheitter, M. L. (1994) Palynology of Lagoa dos Patos sediments, Rio Grande do Sul, Brazil. J. Paleolimnol. 10: 35-42.

Fontana, C. S. (1994) História Natural de Heteroxolmis dominicana (Vieillot 1823) (Aves, Tyrannidae) com ênfase na relação ecológica com Xanthopsar flavus (Gmelin 1788) (Aves, Icteridae), no nordeste do Rio Grande do Sul. Msc thesis. Pontifícia Universidade Católica do Rio Grande do Sul, Porto Alegre.

Fraga, R. M. (1990) El Tordo Amarillo al borde de la extinción. Neustras Aves 23: 13-15.

Fraga, R. M., Casañas, H. and Pugnali, G. (1998) Natural history and conservation of the endangered Saffron-cowled Blackbird Xanthopsar flavus in Argentina. Bird Conserv. Internatnl 8: 255-267.

Gibson, E. (1918) Further ornithological notes from the neighborhood of Cape San Antonio, province of Buenos Ayres. Ibis 10: 363-415.

Hellmayr, C. E. (1937) Catalogue of birds of the Americas, X. Field Mus. Nat. Hist. Zool. Ser. 13 (Publ. 381).

IBGE (1986) Levantamento de recursos naturais; folha SH.22 Porto Alegre e parte das folhas SH.21 Uruguaiana e SI.22 Lagoa Mirim. Rio de Janeiro: IBGE.

Von Ihering, H.(1899) As aves do Estado do Rio Grande do Sul. Porto Alegre. Pp. 113154 in Annuário do Estado do Rio Grande do Sul para o Anno 1900.

Klimaitis, J. F. (1984) Hallazgo del Tordo de Cabeza Amarilla en la Provincia de Entre Ríos. Nuestras Aves 4: 7-8.

Klimaitis, J. F. (1986) Observaciones sobre el Varillero Amarillo en la Provincia de Entre Ríos, Argentina. Bol. Garaganchillo 1: 1-4.

Mähler, J. K. F., Jr, Kindel, A. and Kindel, E. A. I. (1996) Lista comentada das espécies de aves da Estação Ecológica do Taim, Rio Grande do Sul, Brasil. Acta Biol. Leopold. 18: 69103.

Parker III, T. A. and Goerck, J. (1997) The importance of national parks and biological reserves to bird conservation in the Atlantic forest region of Brazil. Pp. 527-541 in J. V. Remsen, Jr., ed. Studies in Neotropical Ornithology honoring Ted Parker. Orni. Monogr. 48.

Parker III, T. A., Stotz, D. F. and Fitzpatrick, J. W. (1996) Ecological and distributional databases. In D. F. Stotz, J. W. Fitzpatrick, T. A. Parker III and D. K. Moskowitz, eds. Neotropical birds: ecology and conservation. Chicago: Chicago University Press.

Ridgely, R. S. and Tudor, G. (1989) The birds of South America, 1. The oscine passerines. Austin: University of Texas Press.

Sick, H. (1997) Ornitologia brasileira. Rio de Janeiro: Nova Fronteira.

RAFAEL ANTUNES DIAS

Museu de História Natural, Universidade Católica de Pelotas, R. Félix da Cunha 412, C.P. 402. 96010-00o, Pelotas, RS, Brasil.

GIOVANNI NACHTIGALL MAURÍCIO

Laboratório de Ornitologia, Museu de Ciências e Tecnologia, PUCRS, Av. Ipiranga, 6681. C.P. 1429, 90619-90o Porto Alegre, RS, Brasil.

Received 22 June 2001; revision accepted 24 April 2002 